\title{
Synergetic effect of financial risk in small and medium enterprises (SMEs)
}

\author{
Dagmar Cagáňová ${ }^{1}$, Alina Kovalenko ${ }^{2 *}$ \\ ${ }^{1}$ Slovak University of Technology in Bratislava, Faculty of Materials Science and \\ Technology in Trnava, Institute of Industrial Engineering and Management. Contact: Bottova \\ 25, 91700 Trnava, \\ ${ }^{2}$ Technical University of Košice, Faculty of Manufacturing Technologies with a seat in \\ Prešov, Bayerova 1, 08001 Prešov, Slovakia \\ \{a.kovalenko_92@ukr.net, dagmar.caganova@stuba.sk\}
}

\begin{abstract}
Small and medium-sized enterprises, in the course of their activities, pursue certain goals, whether to be augmenting capital or entering the international market. In this regard, on the way the managers and the management of the company have tasks that require an early solution with maximum benefit to the enterprise and minimal financial costs. Thus, the main task of the risk manager is to analyse the possible situation, rationally use the company's resources with minimal losses as a result. It is also important for the manager to predict what the company is waiting for at the last stage of implementing the decision in the fight against the risk situation. It should be noted that in the European Union the political and economic situation is somewhat destabilized which affects the economic activities of enterprises.

Therefore, this article has a weight for managers and managers of small and mediumsized enterprises, as they consider the main characteristics of financial risk, their impact on companies' activities, and also consider the synergistic effects of this type of risk on the further development of enterprises.
\end{abstract}

Keywords: small and medium enterprises, main characteristics of risk, financial risk, threats and possibilities of SMEs, methods of financial risk management, synergistic effects of financial risk. 


\section{Basic material statement}

Basic material statement. Small and medium business plays a key role in the formation of an effective state economy. But in the process of the main activity of the enterprise and achievement of the set goal, managers face various risks. In dealing with risk, the manager must have full information, such as the source of the risk, the type of risk situation, the analysis and forecasting of the risk situation, and how the existing risk will affect the further development of the enterprise. Ideally, when the risk can be used at a profit for the company or at the lowest cost.

To compare the risk characterization, there is several definitions from the different authors.

The risk is:

- Loss option.

- Uncertainty in achieving results.

- Deviation from the expected result.

- Danger of incorrect decision [2].

- Business failure.

- Uncertainties arising from the development of assets and their values.

- Condition of incomplete knowledge [3].

- The likelihood of unfavourable alternatives [4].

- Uncertainty about future developments [5].

- Impact of uncertainty on goals [8].

Typical sources of risk include change and uncertainty for various types of reasons:

- The political environment includes government policy, public opinion, legislation, riots.

- Environment includes the Environmental Protection Act, environmental regulations, permits, liability for pollution, weather, earthquakes, fires.

- Marketplace where demand, competition, customer satisfaction emerges.

- Economic environment and associated taxes, inflation, interest rates, rates.

- Financial environment, including bankruptcy, insurance, profit sharing.

- Projects and related strategies, supplies, standards, planning, quality management, program, labour resources. 
- A human factor brings risk in the form of mistakes, exhaustion, poor communication skills [6].

According to the authors [7], sources of risk arise from the external or internal environment of the organization. They belong here:

- Decline in sales, changes in consumer preferences, leading to more significant changes in demand.

- Changes in product sales prices, changes in raw material prices, materials, energy, wages and inputs.

- Changes in the tax system, changes in environmental adjustments, i.e. macroeconomic changes.

- Crisis in the regions, political conflicts in general as changes in the international economic and political environment.

- The lack of production capacity, which affects the sales, also the production costs and their height.

Pure risk - the net risk represents the risk of only negative deviations from the planned situation. Includes damage and loss of property, damage to health. Net risk is also denoted by terms such as insurable risk, static, measurable risk, and so on [10].

Net risk can be divided into the following groups:

- Property Risks - Undertakings are exposed to property risks, which include property losses, loss of income from property and additional expenses incurred by the loss of property.

- Risks of Liability for Damage - arising as a result of negligence as unintentional damage to persons or property. These risks include the incurring of additional expenses due to property damage, property loss, or legal liability arising from an unintentional or deliberate act. Risks arising from the failure of other entities - These risks can be divided into two categories. First, we pose a threat to production due to the failure of energy suppliers, materials, parts, and so on. The second category consists of the risks incurred when the debtor fails to make payments at agreed times [10].

Business risk - Business risk brings elements of uncertainty to business activity. It means that these elements can influence the course of economic activity and, ultimately, endanger the results [3].

Business risk can be assessed from two sides, such as: 
- Positive site - hope for higher profits, higher success. The business entity acts motivationally.

- Negative pages - Dangers of worse economic results, losses, eventual extinction of the business [2]

Types of business risk vary especially due to the focus on a particular business area and substance content. That is why there are distinguished the following risks in particular [3]:

- technical,

- production,

- economic,

- business,

- financial,

- legislative,

- political,

- information.

Before considering some of the specific techniques available for organizations to identify risks, several important factors should be noted about this process [11]:

- The end result of the process should be a risk language specific to the company or the unit, function, activity, or process (whatever is the focal point).

- Using a combination of techniques may produce a more comprehensive list of risks than would reliance on a single method.

- The techniques used should encourage open and frank discussion, and individuals should not fear reprisal for expressing their concerns about potential events that would give rise to risks resulting in major loss to the company.

- The process should involve a cross-functional and diverse team both for the perspectives such a group provides and to build commitment to ERM.

- Finally, the process will probably generate a lengthy list of risks, and the key is to focus on the "vital few" rather than the "trivial many."

Some techniques for identifying the risk are as follows:

- Brainstorming 
- Event inventories and loss event data,

- Interviews and self-assessment,

- Facilitated workshops,

- SWOT (Strengths, Weaknesses, Opportunities, Threats) analysis,

- Risk questionnaires and surveys,

- Scenario analysis,

- Using technology,

- Other techniques (for example, external consultants).

For a more detailed study of the synergistic effect of the risk situation in small and mediumsized businesses, one of the types should be highlighted. In connection with the political changes in the European Union, it should be noted that the economic component will also change somewhat. The consequence of political and economic instability will be the complication of the development of the enterprise in the country of the European Union. Therefore, this article will analyse the financial risk in a small and medium enterprise.

In 2005, the Institute of Chartered Accountants and BDO Stoy Hayward conducted a research study among 183 mid-sized UK enterprises and identified seven key dimensions in which midsize businesses are different from others in the SME grouping. M Institute extended the ideas in the ICAEW / BDO Stoy Hayward report to contrast medium enterprise with small and large organisations in nine different areas. Interestingly, in many ways, medium business is rather more like large business in its behaviour and characteristics, which makes it even more incongruous that medium business is compartmentalised with small business via the SME definition. These differences are summarised in the table below [14].

Table 1. Differences of the enterprises

\begin{tabular}{|l|c|}
\hline Small business & Medium business \\
\hline Owner-managed & Owners plus professionals in key \\
leadership roles \\
\hline Micro-management of employees & Empowerment of employees \\
\hline Informal processes & Formal processes \\
\hline Short-term planning horizon & Longer-term planning horizon \\
\hline Low external input & External input from professionals \\
\hline Equity held by fonder/family & Wider equity base \\
\hline
\end{tabular}




\begin{tabular}{|c|cc|}
\hline \multicolumn{2}{|c|}{ Small customer base } & \multicolumn{2}{|c|}{ Diversified customer base } \\
\hline $\begin{array}{c}\text { Limited personal development } \\
\text { opportunities }\end{array}$ & $\begin{array}{c}\text { Culture enables employee/ } \\
\text { management development }\end{array}$ \\
\hline Low borrowing requirement - & Borrowing needed long- \\
government support possible & term/funding available shorter term & \\
\hline
\end{tabular}

Before investigating the risk, first of all, there should also be understand the characteristic differences between a small and medium enterprise.

Financial risk means the assumption of a financial loss as a result of the contradictory development as compared to the expected development [15]. This risk includes the relationship between the entity (individual, organization) and property, or the expected income that can be reduced [2].

Financial risk is usually affected by three factors, namely:

A threat that can cause a loss. Activity (Income), which reduces the value, destroys or changes ownership of a financial loss. An entity that is exposed to loss [2].

If the relationship of the financial market segment is chosen as the basis for the classification of financial risks, we receive the risks associated with:

- Money markets (bills, treasury bills, bonds, etc.).

- Foreign exchange market (foreign currencies).

- Capital market (shares, mortgage bonds, bonds, etc.).

- Insurance market (reinsurance, insurance).

- The precious metal market (silver, gold, platinum, etc.).

- The derivatives market (options, forwards, futures, derivatives of next generation) [9]. The enterprise with its attitude to risk and disposition tools is able to influence the amount of potential losses and the likelihood of their occurrence. Defining the phases and their quantification creates an idea of the riskiness of the position [9]. 


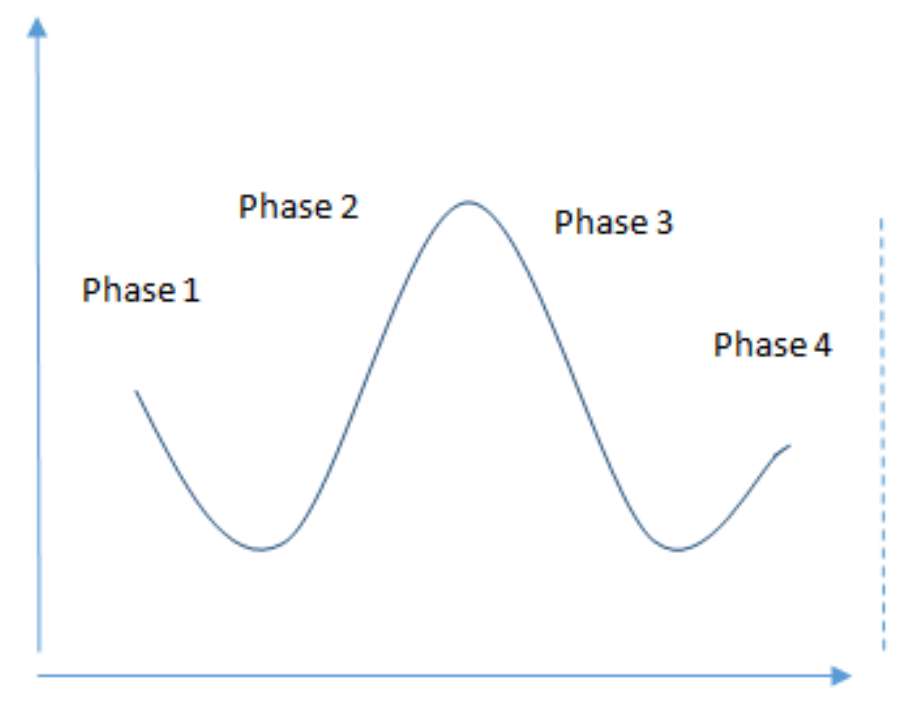

$\mathrm{P}$

Fig.1 Phases of the enterprises

Phase 1 = formation risk

The emergence of financial risk is usually triggered by an external stimulus. For example, by acquiring an asset component that is sensitive to market changes.

Phase 2 = effect of risk

This phase is reflected in financial losses due to market movements, interest rates, exchange rates, and so on. Increasing awareness, the company has both positive and negative experiences. The danger at this stage is that the company is in a stressful situation and can take unwise steps.

Phase 3 = reduction of the impact of risk

The phase where an enterprise typically applies financial mitigation tools. That's what the economic consequences are. The cost of the security that needs to be reimbursed is increasing.

Phase $4=$ risk extinction 
It's the last phase. This is the very disappearance of the risk that may be caused by:

- Extinction of risk - as a result of the sale of the tool

- Extinction of risk - as a result of the expiration of the tool [9].

Risks and threats faced by employees of small and medium-sized businesses are characterized by the nature of the impact, methods of combating risk and results. Those methods that small businesses use in their activities may not correspond to the needs of a medium-sized enterprise and vice versa. To financial threats that may occur in the process of a small business may be included in the following:

- Low level of investments and financing. The enterprise can be specialized and engage in narrow-profile activities. But even such an enterprise needs investments and additional financing. For example, the additional purchase of raw materials (if the company aims to improve the quality of products), training specialists (existing at the enterprise and training new personnel in connection with the needs of the enterprise), changing the organizational structure (if the company aims to expand its horizons).

- Absence of internal financial development. The authors of the papers are dealing with the fact that the main goal of any enterprise is profit. Thus, if the enterprise in its activities goes into 0 or in a marginal profit, this indicates that the financial policy of the enterprise is at great risk. In this case, if the company management does not take certain measures, the company may become bankrupt and cease operations.

- Ineffective/inexpedient allocation of funds to current costs. The financial director, as well as the company's management, should clearly allocate funds for various needs of the enterprise. If the financial flows are not clear and transparent, not only the quality of products will suffer, but also employees of the whole enterprise. It should be analysed what is better to spend this quarter in the quarter, for example, on training a specialist or on top quality raw materials. Here the manager should calculate what costs in the future will bring greater profits.

The results that will entail these financial threats at a small enterprise can be:

- Decline in purchasing power.

- Reducing the number of products.

- Decreased product quality. 
- Decrease or absence of training and development of personnel.

- Deterioration of the marketing system in the enterprise.

- Lack of further development prospects for the company.

- Absorption of the company by a stronger company.

As far as the activities of the average enterprise, the threats can be the same as for the small one. They differ only in that they can concern the structural unit. For example, the department of human resources, which deals with the selection and development of cadres for the enterprise. When an enterprise faces certain financial threats, this particular unit will be affected as the first one. The main reason is the means to better spend on improving the quality of products and purchasing new raw materials, searching for new suppliers. In this case, the risk manager of the enterprise must calculate the costs of training and development of personnel in a given period and the expenditure on raw materials and the change of production. It is possible that in this time period it will be better for the company to devote time to personnel, who, after passing seminars and lectures, will be able to establish production and avoid the risk of the enterprise, and also to direct this type of risk to multiplying the profit of the enterprise.

Threats that occur along the way for the whole company can be such:

- Increased production costs. For example, the company's management decides to enter the international sales market. This will require certification of products, certification of the enterprise, possibly a change of suppliers and raw materials. All this requires additional costs. But in the event that the financial enterprise is not ready for such development, additional risks may arise, for example, staff reduction, a decrease in product quality, etc.

- Economic instability of the country. This includes inflation, changes in the percentage of currencies, changes in the percentage of loans. The price policy of the market and of a single enterprise is formed relative to the country's currency market. If the analysis and forecast of the percentage change in currencies are not carried out, the enterprise may lose a fairly substantial part of the financial capital. The same should be taken into account with the growth of inflation and changes in lending conditions.

- Change in the organizational structure of the enterprise, increase in divisions. The change or correction of the existing organizational structure also entails additional costs. If 
there is considered the formation of a new structural unit in the enterprise, it should be necessary to deal with the fact that this innovation will entail costs for the organization of the working space, training and development of new employees. The risk manager at this time stage should calculate all the threats and possible risks of this innovation for the entire enterprise.

The likely outcomes that will arise from these threats are as follows:

- Possible deterioration in the quality of products in the race for increasing the output quantity. Sooner or later, enterprise managers want to bring their enterprise to the international market. Thus, the number of products must increase significantly. Managers can also divide products into two markets: state and international. However, it should be noted that often the quality of products that are being prepared for the state market differs significantly from those that are produced on the international market. Start saving on materials, finding suppliers with low prices, etc. This leads to a reduction in demand for products, a decrease in profits. Buyers who are accustomed to receive quality products from the enterprise, for the same price can already buy goods of lower quality. An enterprise can lose confidence about customers and incur losses. It should be noted that the control of the quality of products, which is being prepared to the international level, can also be weakened by the shift of all attention to the first group of goods. Then the enterprise can lose a significant part of its assets due to unavailability. So far, it is advisable to distribute financial and human resources at the moment of ungrouping the products and entering the new market.

- Decreased competitiveness of the enterprise. Considering the case, if an enterprise is a supplier of its goods. In the event that management misallocates funds and struggles with possible external financial risks (the country's economy, the country's policy, changes in the state sales market, etc.), the company is able to lose a significant part of customers, which also leads to possible further non-competitiveness, deterioration, further development of the enterprise, and of course, a significant reduction in the company's income.

- Merger of an enterprise with an equivalent enterprise or a stronger one. In the case of the inability to deal with financial risks on its own, the company's management will begin to look for the additional solutions to the situation that has arisen. These ways can be external investment, additional loans or merger with a stronger and more stable company in the market. 
The methods that risk managers will use in combating risk for both enterprises may be the same. Let us consider them in more detail $[12,17]$.

1. Evasion of risk. This implies the refusal to perform any operation, which in themselves is accompanied by a high degree of risk.

2. Acceptance of risk. Here we are talking about the activation of the capital of the enterprise, which will be involved in the process of carrying out any actions accompanied by risky situations.

3. Diversification. The distribution of capital between different types of activities that are not related.

4. Restriction. It is about accepting the risk and distributing administrative powers between individual employees at the enterprise or between structural divisions.

5. Hedging. Protection against possible losses through a balancing transaction.

6. Transfer (outsourcing). Responsibility for the result of the fight against risks and the adoption of a certain decision is assigned to the external organization/party.

7. Insurance. Decrease in participation or full refusal to cover losses in the process of combating risk on the insurer company for a fee.

The results of financial risk in enterprises can also be the synergy of the types of risk. Synergy means the interaction of individual components and that as a result, the total sum of the components will give greater benefit than the individual components. Consider the synergy of financial risk in small and medium-sized enterprises by the example of existing types of financial risk.

So, the financial risk is classified into $[13,16]$ :

Foreign exchange, which in turn is divided into economic risk, transfer risk and transaction risk.

2. Credit risk. 
3. Investment, which is divided into capital risk, selective, interest rate risk, country, operational risk, time risk, the risk of legislative changes, liquidity risk and inflationary.

Further, it is necessary to take into account the possible risk of transfer, which is characterized by the complexity of conducting in accounting transactions. And also the risk of the transaction - the evaluation of the value of its products according to the criteria of the producer country and the real cost of the products according to the criteria of the buyer market may differ significantly.

\section{Conclusion}

So, what is the synergistic effect of financial risk for a small and medium enterprise? The risk of transfer and the risk of the transaction in the amount will incur a significant loss of the enterprise's capital, a possible remainder of the goods that will be difficult to sell on the state market, a reduction in financial flows for the development of structural units and personnel, a decrease in demand for products due to forced savings in the quality of products, transaction or conclusion of a deal with the buyer company on unfavourable terms for the supplier company, a reduction in production volumes and a decrease in the level of the competitor. The authors of the paper should also consider the other side for enterprises when exporting products to the international market. It is possible to consider the correlation of economic risk and transaction risk. Let's imagine that the state currency of the supplier company is different from the national currency of the international market, on which the enterprise enters (for example, the Ukrainian producer enters the Slovak market). Thus, initially for the enterprise there will be a threat of capital decrease due to the costs of product certification, production organization standards, the costs of supplying goods from Ukraine to Slovakia, additional funds for organizing work in another country, and also with possible increase in production costs. But after concluding a deal with the buyer company, all further operations are carried out in national currency for the buyer country, that is, in Euros. Considering the political and economic situation in Ukraine, the sale of products in Euros for the supplier company will bring significant profits. Synergy here plays the role of augmenting equity capital and possible further development of the enterprise not only within the producer country, but also on the international market. 


\section{References}

1. Small Business Enterprises: Meaning, Characteristics and Problems, [Online], Retrieved from:http://www.yourarticlelibrary.com/business/small-business-enterprises/smallbusiness-enterprises-meaning-characteristics-and-problems/69496/

2. SMEJKAL, Vladimír; RAIS, Karel: Rízení rizik ve firmách a jiných organizacích. Praha: Grada Publishing, a.s., 2006. 300 s. ISBN 80-247-1667-4.

3. BUGANOVÁ, Katarína; HUDÁKOVÁ, Mária a kol.: Manažment rizika v podniku. Žilina: Žilinská univerzita v Žiline/EDIS - vydavatel'stvo ŽU, 2012. 226 s. ISBN 978-80554-04592.

4. VLACHYNSKÝ, Karol a kolektív: Podnikové financie. Bratislava: SÚVAHA, spol. s r. o., 2002. 508 s. ISBN 80-88727-48-0.

5. KORECKÝ, Michal; TRKOVSKÝ Václav: Management rizik projektů. Praha: Grada Publishing, a.s., 2011. 584 s. ISBN 978-80-247-3221-3.

6. MERNA, Tony; AL-THANI, Faisal F.: Risk management, Řízení rizik ve firmě. Brno: Computer Press, a. s., 2007. 194 s. ISBN 978-80-251-1547-3.

7. MAJDÚCHOVÁ, Helena; NEUMANNOVÁ, Anna: Podnik a podnikanie. Bratislava: SPRINT, 2006. 232 s. ISBN 80-890-8588-0.

8. RYBAROVÁ, Daniela; GRISÁKOVÁ, Nora: Podnikatel'ské riziko. Bratislava: luraEdition, spol. s r. o., 2010. 179 s. ISBN 978-80-8078-377-8.

9. MARKOVIČ, Peter: Finančné riziko vo finančnom rozhodovaní podniku. Bratislava: Ekonóm, 2003. 120 s. ISBN 80-225-1667-8.

10. VARCHOLOVÁ, Tatiana; DUBOVICKÁ, Lenka: Nový manažment rizika. Bratislava: luraEdition, spol. s r. o., 2008. 196 s. ISBN 978-80-8078-191-0.

11. Enterprise Risk Management: Tools and Techniques for Effective Implementation - The Association of Accountants and Financial Professionals in Business, [Online], Retrieved from: https://www.imanet.org/insights-and-trends/risk--management/test?ssopc=1 [2007].

12. Lecture course by E. Shohin, [Online], Retrieved from: https://studme.org/1209081011391/finansy/metody_upravleniya_finansovymi_riskami

13. Lecture course, [Online], Retrieved from: http://www.grandars.ru/student/fin$\mathrm{m} /$ finansovyy-risk-predpriyatiya.html

14. Understanding medium enterprise, [Online], Retrieved from: http://www.minstitute.org/m_institute/understanding-medium-enterprise.html

15. MARKOVIČ, Peter a kolektív: Manažment finančných rizík podniku, Implementácia derivátových kontraktov. Bratislava: IuraEdition, spol. s r. o., 2007. 383 s. ISBN 978-808078-132-3.

16. Balog et al. Plánovanie v strojárskej výrobe (in Slovak). Brno, Tribun EU-2016,ISBN 97880-263-1078-5

17. Balog,M., Lajtoch, J. Ř́zení rizík v samosprávě (In Czech), 1. vyd. - Brno : Tribun EU 2016. - 130 p.. - ISBN 978-80-263-1155-3. 